\title{
Post-socialist agricultural cooperatives in Russia: a case study of top-down cooperatives in the Belgorod region
}

\section{Alexander Kurakin \& Oane Visser}

To cite this article: Alexander Kurakin \& Oane Visser (2017) Post-socialist agricultural cooperatives in Russia: a case study of top-down cooperatives in the Belgorod region, PostCommunist Economies, 29:2, 158-181, DOI: 10.1080/14631377.2016.1267974

To link to this article: https://doi.org/10.1080/14631377.2016.1267974

曲 Published online: 13 Feb 2017.

Submit your article to this journal $₫$

Џ Article views: 96

Q View related articles ¿

View Crossmark data $\nearrow$ 


\title{
Post-socialist agricultural cooperatives in Russia: a case study of top-down cooperatives in the Belgorod region
}

\author{
Alexander Kurakin ${ }^{\mathrm{a}}$ and Oane Visser ${ }^{\mathrm{b}}$ \\ aLaboratory for Studies in Economic Sociology, National Research University Higher School of Economics \\ (HSE), Moscow, Russia; ' International Institute of Social Studies (ISS) of Erasmus University Rotterdam, The \\ Hague, The Netherlands
}

\begin{abstract}
Through a study of agricultural service cooperatives in Russia's Belgorod region, this article addresses two gaps in the literature: first, the dearth of empirical studies on cooperatives in post-socialist Russia; second, the lack of attention to top-down cooperatives in the global literature, and the overly negative approach to the topic in the few extant studies. Whereas state attempts to establish agricultural cooperatives in Russia in a top-down fashion have largely failed, such cooperatives have sprung up widely in Belgorod. The article investigates: (1) what influence the (regional) state exerts on the cooperatives, and how that affects their daily functioning and viability; and (2) to what extent such top-down cooperatives might evolve into less state-led forms, such as classic member-driven or business-like cooperatives.
\end{abstract}

\section{ARTICLE HISTORY}

Received 16 January 2016

Accepted 25 April 2016

\section{KEYWORDS}

Cooperatives; top-down cooperatives; Russia; agriculture; social capital

\section{Introduction: the issue of top-down cooperatives}

The global literature on agricultural producers' organisations - also referred to as agricultural cooperatives - has a rich tradition of studies in the Global South, as well as in the West. ${ }^{1}$ To date, the countries of post-socialist Eurasia, including the former Soviet Union, China and Central Eastern Europe (CEE), have attracted much less attention. In particular, the post-Soviet region - with Russia as its biggest country - has largely been ignored.

This is especially remarkable when one considers Russia's rich early history of cooperatives, and the extended literature on Russian cooperatives and family farms, which is generally associated with the work of Chayanov ([1927] 1991) and gained importance in agrarian studies in the 1970s through authors such as Shanin (1971). Agricultural cooperatives flourished in Russia in the pre-Soviet period of the early twentieth century (Bilimovich, [1955] 2005; Kotsonis, 1999; Pallot, 1998). By 1914, the agricultural cooperative movement had become the largest in Europe, with over nine million members (Kotsonis, 1999). However, with the onset of communism and forced collectivisation, voluntary cooperatives were replaced by obligatory membership of collective and state farms.

Very few comprehensive studies have been carried out on the fate of cooperatives after the demise of the communist system in 1991, and the subsequent decollectivisation. A 
reason that the topic has been neglected is the assumption made by observers of post-Soviet agriculture that rural cooperatives have played a small role in development in rural Russia and, so the argument goes, are unlikely to become sites of dynamic growth in the future. ${ }^{2}$ Instead, attention focused on private family farms (in the early 1990s) and, when the emergence of those farms stagnated, on large farm enterprises (from the mid-1990s onwards). The view that cooperatives had a small role to play was reinforced by the fact that the Russian cooperatives that emerged are generally economically very weak and fragile, and that no cooperative movement emerged in Russia (Fedorov, 2013; Golovina \& Nilsson, 2009, 2011). As classical cooperatives are perceived as an exclusively bottom-up activity of selforganisation, they could be considered as an outcome of various social movements (Gutiérrez, Atela, \& Duenas, 2005), having similar prerequisites like social capital. Mamonova and Visser (2014) though suggest that rural organisations and movements in post-Soviet Russia are slow to emerge, if they do so at all. ${ }^{3}$ This is the case for a number of reasons, including the low level of social capital (in the sense of self-organisation capacity at the meso-level of rural communities) in Russia, ${ }^{4}$ (Murray, 2006; O'Brien et al., 2000, 2005; Visser, 2008, 2010), the ambivalent impact of marketisation and the ideological disillusionment of the population (Humphrey, 1999) which ultimately discredited the cooperative notion (Golovina, 2012). ${ }^{5}$ In the specific case of agricultural cooperatives, the out-migration of young and ambitious social strata and the subsequent ageing of the rural population are further obstacles to the development of a vibrant cooperative movement (Golovina, 2012; Visser, 2010).

Here we deal with service (consumer) cooperatives only, leaving aside production cooperatives which are also present in post-socialist countries. The cooperatives studied here provide primarily marketing services to their members, so they could also be called marketing cooperatives. Russian legislation distinguishes between two major types of agricultural cooperatives: consumer cooperatives and production cooperatives (in the law 'On agricultural cooperation'). The former are defined as non-profit organisations and the latter as commercial. In legal terms, consumer cooperatives include marketing, supply, processing and credit cooperatives, whereas the main goal of agricultural production cooperatives is collective production (see details in the section 'Agricultural cooperatives in Russia: terminology and trends').

In this article we show that cooperatives in Belgorod are mostly established in a top-down fashion, a finding that resonates with that of Golovina and Nilsson $(2009,2011)$ in the Kurgan region. The global literature largely ignores top-down cooperatives, ${ }^{6}$ which are generally seen in a negative light, comparing unfavourably with the classic Western-European cooperatives. From the very origins of cooperative theory (particularly the basic cooperative principle of 'autonomy and independence') this view is predominant among Western scholars (e.g. Bijman et al., 2012 ) and international development organisations such as the World Bank and ILO (2001). Top-down organisation of cooperatives is widely assumed to discourage genuine member involvement (Barton, 1989; Dunn, 1988). Studies on transition countries by Western scholars and international agencies generally perceive top-down cooperatives as ineffective or even as a comeback of socialism (Bijman et al., 2012; ILO, 2001). However, in developing countries and emerging economies, they are sometimes acknowledged as a legitimate way of organising cooperatives (Mendoza \& Castillo, 2006). Recent studies on China suggest that agricultural cooperatives with active state involvement and little voluntary farmer participation are quite widespread (Liang \& Hendrikse, 2013; Lin \& Huang, 2007) and can function effectively (Deng, Huang, Xu, \& Rozelle, 2010, p. 497 ). In addition, a study 
by Rankin and Russell (2005) on post-socialist Vietnam indicates that farmer initiative was weak and state organisational involvement was the key factor in the development of agricultural cooperatives.

Little is known about the functioning and viability of such cooperatives, or about the prospects for their development into more member-based cooperatives over time. ${ }^{7}$ This article places these overlooked cooperatives in the spotlight, and aims to provide a more balanced, empirically grounded assessment of their functioning and prospects. Thus, we do not present another case of the difficulties of establishing grassroots cooperatives in postsocialist countries. Instead, we take this problem as a given, and study top-down established and governed cooperatives as a potential solution in settings where the prospects for genuine, bottom-up cooperatives are currently limited.

Our study contributes to the recent literature on agricultural cooperatives in post-socialist countries. In so doing, it goes beyond an overly negative view of top-down cooperatives, and tries to assess their various benefits, limitations and downsides in the specific context of post-socialist, emerging and insecure economies with weak institutions. We focus on de novo (newly established) top-down cooperatives, as opposed to the successors of the Soviet collective farms. Such top-down organised cooperatives can be found in post-socialist settings, in several former Soviet republics such as Armenia, Belarus and Georgia (White \& Gorton, 2006), and in reform-socialist China (Deng et al., 2010; Sultan, Larsén, \& Huang, 2011). We build on work by Golovina and Nilsson $(2009,2011)$, who examined top-down established cooperatives in Russia (Kurgan region) based on surveys, while we provide a multi-case study approach based on qualitative research.

We address two main issues. First, we determine the state's influence on these top-down established cooperatives, and its effect on their viability/functioning. We do so by focusing our analysis on the state's influence on the daily operations of the cooperatives within the food chain. We find that - in a context of weak institutions and a hostile environment for small-scale farms - the top-down nature of established cooperatives has clear advantages at the start of their development; however, it also has some weaknesses, especially in the medium/long run. Second, we explore the extent to which such top-down established cooperatives might, over time, evolve into more 'common', less state-controlled and patronised (and subsequently more independent from the state in their daily operations) types of cooperatives (e.g. the classic cooperatives, or business-like cooperatives).

Our study investigates the implications of the cooperatives' top-down organisation, as reflected in their daily practices and functioning. Although we do discuss the policy environment extensively, we go beyond policy aims and formal implementation (e.g. in terms of number of cooperatives created and members involved) and look explicitly at the informal, everyday interaction between state officials and cooperatives. The latter, as we will show, is crucial in understanding the functioning, prospects, as well as the tensions and limitations of this type of cooperative. Our attention to everyday functioning informed our decision to use qualitative research methods. Our study thus differs from, and complements, the sparse research on cooperatives in Russia and the post-Soviet region, which is typically characterised by quantitative methods (see e.g. Golovina \& Nilsson, 2009, 2011; Yanbykh, Starchenko, Mindrin, Tkach, \& Krylov, 2012 ).

This article is exploratory in nature, as the research is still ongoing, and as this study is the first attempt at research of a more qualitative nature in the selected context. By giving insight into the functioning of top-down cooperatives through a few selected case studies, 
this article will thus present some tentative conclusions on the further development of such cooperatives, and suggest directions for further research.

The article is structured as follows. First, we describe our methods and fieldwork region. Second, we provide a brief background of the Russian agricultural system, its structure, and cooperative development nationwide and in the Belgorod region. In the third section, we argue that Belgorod's policy to promote rural cooperation brought about some positive results, especially in comparison to Russia at large and the Kurgan region specifically, where the process of cooperative emergence has been studied by Golovina and Nilsson (2009, 2011) on the basis of primary data collection. In the fourth section, we analyse the reasons for the comparatively positive results in Belgorod. In the fifth section we consider whether such top-down cooperatives might, over time, convert into member-controlled cooperatives. In the conclusion, we synthesise our findings on the extent (and effect) of state influence on the cooperatives, their functioning in practice and their prospects. When addressing the conversion prospects of top-down established cooperatives, we will make use of historical (and international) analogies.

\section{Methodology and regional background}

Belgorod is interesting as a research region for two reasons. First, it features highly successful growth rates in the agricultural sector. Secondly, as mentioned earlier, it stands out in terms of its cooperative development.

Belgorod is located in the fertile Central Black Earth region, bordering Ukraine. As one of the smallest regions in Russia, Belgorod holds fourth place in the country's agricultural output in 2012 (Rosstat, 2013b), with a strong focus on livestock production, especially poultry and pork. In 2012, it even ranked first in Russia in terms of pig headcount, with every fifth pig in Russia located in the Belgorod region (Rosstat, 2013b). It is also the number one region for meat production in terms of cattle, pigs and poultry (measured in slaughter weight). ${ }^{8}$ This success is based primarily on the development of large-scale farm enterprises in the form of agroholdings - integrated companies consisting of multiple farm enterprises and often other firms in the food chains; in fact, the Belgorod region is perceived as being entirely dominated by agroholdings (Epshtein, Hahlbrock, \& Wandel, 2013). However, at the same time, Belgorod has actively supported the small-scale farming sector, in particular through the development of cooperatives.

This article is based on qualitative fieldwork conducted by the authors in the Belgorod region in the autumn of 2010, the summer of 2011 and the autumn of 2013, which consisted of focus group discussions (FGDs), in-depth interviews and observations. Being part of a broader research project on agrarian policy in Belgorod, the research for this article began with a comparative case study of two cooperatives: a large dairy cooperative, and a vegetable cooperative. Specifically, two focus group discussions were conducted in the dairy cooperative's milk stations (Author 1), and one FGD was conducted with one of the main purchasers of the vegetable cooperative's products (the purchaser being a kindergarten) (Author 1). Each FGD included a diverse set of actors: cooperative managers, members, hired staff (non-members), external contractors and district state officials responsible for promoting cooperation. These FGDs provided the core empirical evidence on the day-to-day performance of Belgorod cooperatives. We then conducted an FGD and interview with the staff of another, smaller dairy cooperative (Author 2). Further, we conducted two interviews with 
district officials concerning cooperative policy (Author 1 \& Author 2), and a third interview with the deputy head of the regional department of agriculture; these three interviews were meant to gather insights into the regional approach of the authorities to cooperatives. Finally, we organised an FGD with regional officials to determine their ideas on the development of small-scale farms in the region (Author 1). Overall, case study information was collected from several stakeholders: the cooperatives themselves (including management, members, employees), actors who contract with cooperatives, district officials and regional officials. Both focus group discussions and interviews were open; although a topic list had been developed, we did not follow it strictly, in order to allow for lively and rich conversation.

Beyond the direct information on cooperatives described above, we collected more than 30 interviews with a wide range of actors: representatives of various types of agricultural producers (large farm enterprises, family farms and household plots), officials at different hierarchical levels and the staff of social organisations (schools, kindergartens, hospitals, culture clubs and sport gyms). Those interviews, for a larger research project, of which the study of cooperatives constituted a part, enabled us to better understand the overall regional context and institutional environment in which cooperatives have to operate.

Proximity to a large urban centre can be an important factor influencing the marketing opportunities and overall development of a cooperative. The field visits covered seven rural districts, which roughly capture variety in distance to the regional capital. A cluster of two districts was selected directly neighbouring the central Belgorod district (around the regional capital), with a distance of $27 \mathrm{~km}$ and $54 \mathrm{~km}$ from the district centre to the regional capital. A case study cooperative was located in one of these districts. Further, the study included a cluster of two districts that were located at the border of the region, with a distance of 170 and $185 \mathrm{~km}$ to the regional capital (the latter is the district furthest away from the regional centre). The other two case study cooperatives were located there. The remaining three districts visited during the research fall in between those two clusters in terms of distance.

Furthermore, government documents, regional articles and data from websites on cooperatives, district administrations and farmers were collected and analysed.

\section{Agricultural producers and farmers' cooperatives in Russia and Belgorod}

\section{Types of agricultural producers}

Soviet agriculture, based primarily on collective and state farms (kolkhozes and sovkhozes) and secondly on small subsidiary household plots, was radically transformed after the demise of the Soviet Union in 1991. Currently, three types of agricultural producers exist which dominate the successors of the above-mentioned producers in terms of their impact on overall agricultural production.

The first type of agricultural producers consists of farm enterprises - which is how we refer to the large-scale successors of state and collective farms in this article. These farm enterprises have various legal forms, such as joint stock or limited liability companies. In the 2000 s, Russia witnessed the entry of outside investors into the agribusiness sector, which occurred through the formation of agroholdings - conglomerations of multiple farm enterprises often also including other types of agribusiness enterprises such as processing firms.

The second type of agricultural producers consists of household plots, another Soviet legacy. The Soviet regime allowed rural dwellers employed at kolkhozes and sovkhozes to 
have small plots of (at most) 0.1 hectares. Despite being ideologically alien, this form of private production and user rights was tolerated to compensate for insufficient food production through collective farms.

The role of the third type of agricultural producers - the newly established private family farms, or simply, farmers (fermery) - is rather modest. Russian reformers - and their World Bank advisors - expected the 1990s agricultural reform and privatisation to lead to a rapid emergence of farmers, who would then become important players in Russian agriculture (Wegren, 1998). In reality, the emergence of farmers was piecemeal in most regions (Pallot \& Nefedova, 2007; Wegren, 1998). ${ }^{9}$ An important obstacle to this process has been the predominance of large-scale input and output channels, which tend to exclude smaller-scale producers and new entrants, who lack personal connections with important actors in the food system (Pallot \& Nefedova, 2007; Wegren, 1998). Although farm enterprises experienced a major downfall during the 1990s, the rural population preferred to remain employed by them and simultaneously increase production on their subsidiary household plots, instead of becoming individual farmers in the risky political-economic environment at the time (Amelina, 2000). As a result, the household plots' share of agricultural output rose drastically in the 1990s (see Figure 1).

One important reason why rural dwellers have preferred plots over independent private farming is the fact that kolkhozes - and, to some extent, farm enterprises - provide(d) households with support services (Pallot \& Nefedova, 2007; Visser, 2003, 2009; Wegren, 1998). These services include, for instance, ploughing, low cost feed grain for household livestock, and promoting household produce through the sales channels of the farm enterprise (Visser, 2003). These services have been (partly) curtailed over the course of the late 1990s and 2000s (with the emergence of outside investors and agroholdings) (Nikulin, 2003; Pallot \& Nefedova, 2007; Visser, 2009). The share of household plots in Russia's total agricultural output value has recently decreased, mainly due to recovery of the large farm enterprises. Nevertheless, they remain a crucial - although largely underestimated - element of Russian agriculture. That being said, the decline of farm enterprises' support of household plots has increased

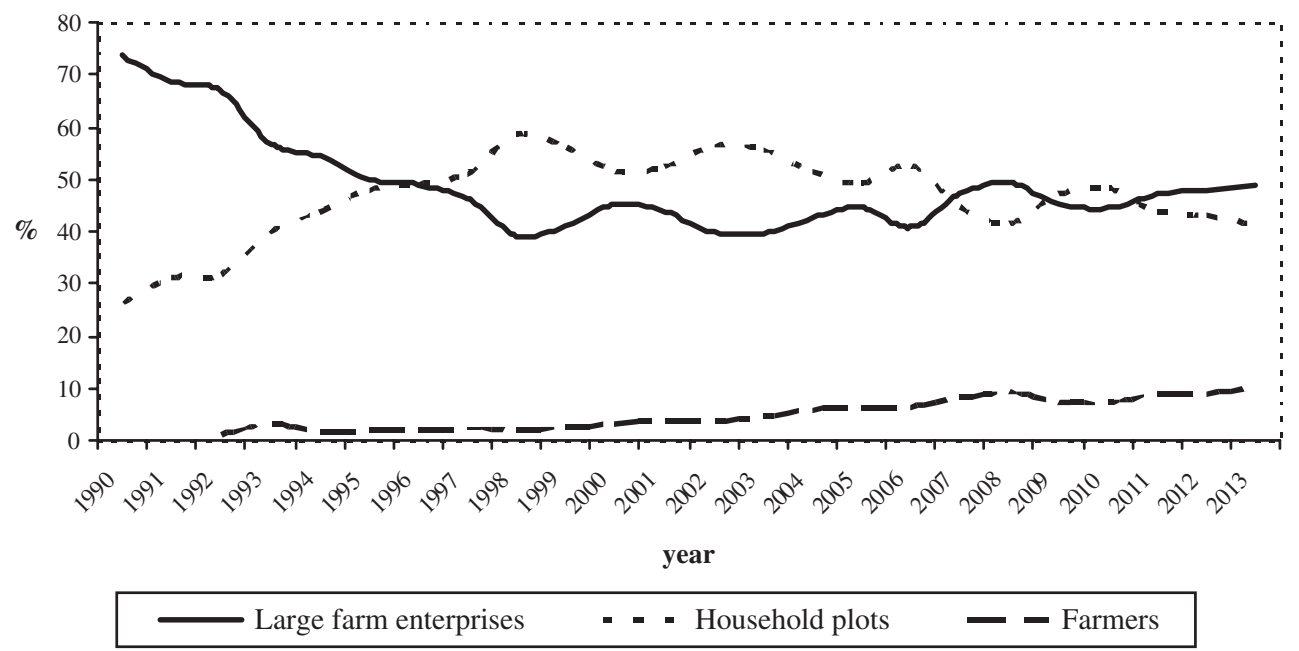

Figure 1. The share of different types of producers in agricultural GDP. Source: Compiled by the authors based on Goskomstat (2000) and Rosstat (2002, 2004, 2013a, 2006, 2009, 2014). 
the need for alternative sales and input channels. As a consequence, the question of cooperatives as a potential solution has become more important.

\section{Agricultural cooperatives in Russia: terminology and trends}

Beyond a few rare exceptions (Nilsson, Golovina, \& Volodina, 2008; Nilsson, Volodina, \& Golovina, 2010; Yanbykh et al., 2012), the Russian literature on cooperatives lacks solid empirical studies - especially at the micro level. ${ }^{10}$ Consequently, we draw on only a few articles concerning agricultural cooperatives in general and top-down cooperatives in particular.

We first clarify our use of the term 'cooperatives', and subsequently 'top-down cooperatives' more specifically. In this article, our empirical results refer to agricultural service cooperatives, which provide services to individual farms, and not to agricultural production cooperatives, where members pool production resources and farm jointly. As noted by Lerman (2013) and Millns (2013), opinions diverge on what constitutes a cooperative in post-socialist contexts. Some studies focus only on the legal label and consider large-scale farm enterprises - the privatised successors of the kolkhozes and sovkhozes - to be cooperatives. For instance, some articles (Golovina, Hess, Nilsson, \&Wolz, 2014; Golovina, Nilsson, \& Wolz, 2012, 2013) examine so-called Russian agricultural production cooperatives (in Russian, SPK) - an organisational form chosen by many former kolkhozes (along with joint stock and limited liability companies) after they were forcefully dissolved in the early 1990s in the course of President Yeltsin's decollectivisation reform. ${ }^{11}$

The post-Soviet agricultural production cooperatives emerged from the ruins of the Soviet collective farms, and were initially perceived by reformers in the Kremlin as a temporary organisational form that would evolve into capitalist, private family farms (Wegren, 1998). However, they survived and remain one of the main legal forms of agricultural producers though some scholars are quite pessimistic about their future (Gardner \& Lerman, 2006). The cooperatives we consider in this article differ from SPKs in that they are newly created (not simply successors of the Soviet collective farms), and perform services for a group of more or less independent small-scale agricultural producers. In this sense those two types of cooperatives have a divergent nature (though cooperative in general), which reflects different trajectories of establishment and not only current laws. In terms of legislation, it is easier for production cooperatives to evolve into a firm (through internal evolution or takeover by an agroholding) than to become a consumer cooperative. In the latter case it should be dissolved first and then reassembled according to the agreement of independent agricultural producers.

The term 'top-down cooperatives' refers to the fact that such cooperatives are not established bottom-up by the members, but instead initiated by the authorities. The Russian government required regions to establish cooperatives and provided some subsidies, but aside from that, the further development of cooperatives depends on the regional authorities.

Despite the small-scale producers'strong need for support in terms of inputs, marketing and financial loans, cooperatives remain underdeveloped in Russia. Many cooperatives are either not active at all in practice, or function badly. As the former Russian Minister of Agriculture stated:

Yet, we have to admit that cooperation does not perform well. This is not laying blame, but a statement. (...) the real number [of active cooperatives] is unknown. Thus, we don't have any 
reasons to claim a well-designed and efficient system. Cooperatives are scattered, fragmented, performing chaotically and uncontrolled (Fedorov, 2013, p. 45).

Cooperatives' success is measured not only by their quantity and member count (though those indicators are important because cooperatives can be efficient only when they have a certain magnitude); after all, cooperatives are not the ultimate goal. Their success is assessed mainly on the services they can provide to small-scale producers and the support to the latter in competition with large enterprises.

Within Russia, we can tentatively distinguish types of regions in terms of development of agricultural service cooperatives. First, most regions show very weak development of cooperatives. The cooperatives in those regions exist largely on paper. Such 'virtual cooperatives' have mostly emerged since 2006 when the national programme, which included a focus on cooperatives, began. The 'virtual cooperatives' have either been established bottom-up with the (unfulfilled) hope of receiving a subsidy, or top-down by the regional authorities just following instructions from Moscow without any intrinsic motivation to make the cooperatives work (cf. Yanbykh et al., 2012). The Kurgan region is a clear example of this type of region (see below).

Second, there are regions where cooperatives have emerged bottom-up to some extent (ILO, 2009; Yanbykh et al., 2012). None of the Central Black Earth regions falls into this category. Instead, it is the regions with substantial ethnic minorities (which tend to have a stronger presence in private and household farming (Pallot \& Nefedova, 2007), and/or a stronger sector of private farmers more generally, which are overrepresented in this category. A clear example of the latter is Volgograd. It is mentioned as one of the four regions in Russia that has more than 100 agricultural cooperatives by Yanbykh et al. (2012), with farmers constituting the core of the membership of these cooperatives.

Third, there are a few regions where the regional authorities have gone beyond just creating cooperatives on paper to meet central government demands, by actively creating and supporting functioning cooperatives. Belgorod is the outspoken example here (Kurakin, 2012; Yanbykh et al., 2012). Probably Tatarstan (ILO, 2009; Yanbykh et al., 2012) and recently Lipetsk (Lipetsk Government, 2012) somewhat resemble the example of Belgorod.

As mentioned earlier, the studies by Golovina and Nilsson $(2009,2011)$ allow us to tentatively compare Belgorod's practices and outcomes of top-down cooperative development with those from another region (Kurgan). As we show below, while the findings of the existing studies are more likely to be representative of cooperative trends in Russia at large (because agricultural consumer cooperatives still perform poorly at the country level), the practices we encountered in Belgorod, although not unique within Russia, appear to be rather divergent from what seems the main pattern found in regions like Kurgan (the first type discussed above). ${ }^{12}$

In the Kurgan region, less than half of the planned cooperatives (21 out of 48) were actually created. Based on regional statistics and data collected up to a year after the cooperatives' establishment, Golovina and Nilsson showed that the established cooperatives had not been successful. Moreover, the authors expected that 'half a year or one year later, many of the co-operatives might already have been dissolved' (Golovina \& Nilsson, 2011, p. 61).

In Belgorod, however, cooperative establishment looks more promising. First, the number of cooperatives in Belgorod is much higher than in Kurgan (465 in 2009 compared to 21 in 2008 , respectively). Thus, even if only a minority of the cooperatives in Belgorod proves to be active in the future, they will still represent a sizeable number. Second, the Belgorod 
cooperatives we studied also featured a substantially higher membership. In Kurgan, the cooperatives had fewer than eight members on average. In Belgorod, the cooperatives we visited had significantly more on average: while the small dairy cooperative had seven members, the vegetable cooperative had 280 members, and the large dairy cooperative had no fewer than 1700. Moreover, while Golovina and Nilsson strongly doubted the Kurgan cooperatives' ability to provide any significant benefits to their members, those we visited in Belgorod already provided some services and benefits, such as providing a market outlet for agricultural produce, and provision of inputs and/or in-kind credits. Moreover, they were planning to add new services and innovations - such as buying larger trucks and establishing processing units. While we cannot claim that our findings represent the entire Belgorod region, our exploratory field studies produced a picture that was quite different from the one in Kurgan.

Having briefly outlined the main differences between the Belgorod and Kurgan regions in terms of existing cooperatives, we now provide a more detailed comparison of government policy on cooperatives and its outcomes in Russia at large and Belgorod in particular.

\section{Cooperative development in the Belgorod region: tangible results in comparison to nationwide failure}

Attempts to establish service cooperatives have been made throughout Russia, not only in the Belgorod and Kurgan regions. So far, as discussed above, the Belgorod region represents a relatively rare positive outcome. The main criterion of success here is not only the number of cooperatives established (as the creation of cooperatives is not the ultimate goal), but their ability to provide services for their members.

After the 1990s' agricultural decline and policy-related urban bias, agriculture became a priority in the 2000s. New state programmes were initiated, including some on cooperatives. The state directed most funds to large farm enterprises - agroholdings in particular (Uzun, 2005). A slight turn towards small-scale farming occurred in 2006-2007, with the national project for the development of agro-industrial complexes (AIC Development). This programme was later transformed into several federal programmes that offer state support for household plot users and farmers, in order to provide some income to the increasing numbers of self-employed or unemployed rural dwellers. An important mechanism within those programmes was the establishment of supply and marketing cooperatives (Barsukova, 2007). These cooperatives are oriented toward small-scale producers, as the large farm enterprises' size can ensure, on the one hand, that most of the farm services, storage and transport facilities are provided for in-house, and on the other, that they occupy a better bargaining position vis-à-vis suppliers and purchasers.

Although those programmes led to the establishment of cooperatives throughout Russia, state monitoring is virtually absent, and reliable official statistics on even basic figures - such as the number of cooperatives in the country - are not freely available for researchers. The Ministry of Agriculture only provides estimates. According to the Ministry, by 2012, 7746 agricultural consumer cooperatives were registered, including 5971 processing, storage, supply and marketing cooperatives, and 1775 credit cooperatives; every third cooperative was inactive (Russian Ministry of Agriculture, 2013). 
The establishment of these cooperatives was largely carried out in a top-down fashion (Franks \& Davydova, 2005; Golovina \& Nilsson, 2011; Kurakin, 2012). Each Russian region was expected to establish cooperatives, and the federal government made agreements with regional administrations about their creation. In turn, the regional governments ordered district authorities to create a certain number of cooperatives. The cooperatives were subsequently established largely by district and/or local authorities themselves, and partly financially supported by these authorities. The cooperatives' management is typically recommended by the government at district or regional level, or at least has good relationships with governmental decision makers. Household plot holders and/or family farms are invited to become members without having to invest any money (except, sometimes, a minimal membership fee) or take on any obligations.

While this same process took place in Kurgan, Belgorod, and other regions, the outcomes differ per region, with Belgorod showing significantly better results compared to the national figures. Significantly, as will be shown, Belgorod's top-down cooperatives provide real services to their members. Although this is a very basic indicator of cooperative success, it allows us to identify the situation in Belgorod as quite divergent from the general Russian trend.

We would argue that these differences stemmed from the'Belgorod family farms' regional programme. First implemented in 2007, the programme created a large number of cooperatives across the countryside, where previously there had been no signs of a sizeable bottom-up cooperative movement in the region. According to official statistics, only 20 agricultural cooperatives existed in the Belgorod region in the year 2000. By 2009, 465 had already been established, including 189 service (processing and marketing) cooperatives (Nikulin, 2009). The programme implemented a standardised approach to every district. According to the regional plan every district should establish between three and four service cooperatives on average (Belgorod Government, 2007). Every district was obliged to establish at least one milk cooperative, one supply cooperative, ${ }^{13}$ and at least one optional cooperative. Typically, the latter targeted niches that were not occupied by large-scale producers (e.g. vegetables, ducks, sheep etc.). Thus, while the Belgorod region itself may be divergent from much of the country, the districts we conducted our fieldwork in were standard in terms of governmental efforts to promote cooperatives in Belgorod.

To explore these issues further, we briefly present and discuss the case of a Belgorod dairy cooperative - whose'heart', a small milk station that graded and refrigerated the cooperative members' milk, was part of our fieldwork. This cooperative was founded in 2007 through the 'Belgorod family farms' regional programme, and was also supported by the district programme'Fresh milk'. In total, the cooperative had seven milk stations and collected milk mainly via its own trucks. Moreover, the cooperative had 41 employees, such as milk station testers, drivers, an engineer, an accountant and security guards. The milk stations provide services for all the districts' settlements, with the milk collected from households accounting for $68 \%$ of the district's cattle headcount (Alekseevsky Municipal Government, 2011) - a headcount that has been stable over the past few years. The cooperatives' activities included purchasing milk from its members (all of them households) and selling it to the local milk processing factory. Apart from a few individual traders at the district central market, the milk factory was the only buyer of the cooperative's milk at the time of our fieldwork. The cooperative also provided in-kind loans to its members, who were allowed to buy cows on credit and pay for them through milk delivery. In addition, the cooperative supported its members by providing fodder for livestock. 
With regard to the fulfilment of the stated aims, the top-down cooperatives we studied were indeed able to provide a stable marketing channel, which rural dwellers had no previous access to. ${ }^{14}$ The cooperatives provided the household producers with a stable sales channel that guaranteed purchase of their product and reliable payments. In addition, the cooperatives offered the household plot holders small-scale credit and access to inputs. In so doing, the cooperatives were 'alive' - that is, providing real services for their members.

How viable are the cooperatives in this region? The Belgorod authorities do not predict significant further growth in their number. This, however, does not necessarily signal the stagnation of the cooperative movement, or its lack of viability; it could simply be the normal economic pattern of saturation - or even overcapacity - in terms of the number of cooperatives. In contrast, Golovina and Nilsson $(2009,2011)$ feared that many cooperatives in the Kurgan region would already be dissolved within one year of being established. Thus, it would be too hasty to interpret the 'stagnation' of the number of cooperatives - or even a decrease in the number of active cooperatives - as evidence of the top-down established cooperatives' failure in the Belgorod region. If nothing else, any form of cooperative (grassroots-based, or business-like) would struggle with such a large number of competitors as those reported in the region.

In the next section, we analyse the causes for the remarkable growth of quite 'healthy' cooperatives in the Belgorod region.

\section{Administratively constructed market niches as the main driver of cooperative development}

The Belgorod regional government administers a range of social programmes, such as rural housing, rural infrastructure projects and rural start-up grants. One of these, as described above, is the 'Belgorod family farms' programme, which provides support to farmers and household plot producers. The Belgorod regional government does not expect the programme participants to be nearly as efficient as agroholdings and farm enterprises more generally. ${ }^{15}$ The authorities do take into account economic motives, but the most important aim is stimulating local, small-scale agricultural production. Belgorod officials regard the latter as a factor in the viability of rural settlements, and as the cure for rural depopulation, alcoholism and indifference. Thus, the programme's declared goals are not economic, but socially-oriented, with the ultimate aim to'reconstruct the mind of the villager and to stimulate him/her to produce competitive market goods' (Belgorod Government, 2007). In more pragmatic terms, the programme's goal is to increase the viability of the self-employed rural dwellers' ventures, and to help them overcome long-term poverty. ${ }^{16}$ The programme focuses on those types of agricultural production where large-scale producers are not the dominant players, such as dairy farming, sheep and rabbit breeding, and beekeeping. As such, it creates market niches for farmers and household plot producers, shielding them from severe competition from large farm enterprises. The development of rural cooperatives is an important part of the 'Belgorod family farms' programme, and is seen as a means of providing a market for small-scale, family producers, for whom the problem of finding sales channels is particularly acute.

The fact that the regional government is attempting to address the issue of rural development beyond window dressing and 'just following Moscow's instructions' is indicated by the special administrative structure that was created to promote, implement and monitor 
the programme. The programme documents describe the administrative structure as a'vertically integrated three-level managerial system: region-district-municipality'. Officials were appointed to manage the implementation of the programme at all three levels, and a special task force was created at the regional level. Furthermore, the programme gets substantial attention from the regional governor (for instance, through visits to producers involved in the programme) and from the regional media.

Now that we have addressed the crucial role of Belgorod's regional administration in the emergence of cooperatives, we turn our attention to its impact on the subsequent operations of these top-down established cooperatives. Specifically, we found that the effect of the local administration is visible beyond the cooperative's founding. From our interviews and focus group discussions, it became clear that the 'Belgorod family farms' programme had created - through strong state influence - complete food chains into which these cooperatives are integrated (Kurakin, 2012). In fact, the local, district and/or regional administrations had established secure market niches for the cooperatives, with guaranteed sales on different levels. This situation is somewhat opposite to the classical case where cooperatives emerge to produce a countervailing power to large firms (see Bijman \& Hendrikse, 2003). In the case of marketing cooperatives, the latter are buyers (for the case of post-Soviet Armenia see Gorton et al., 2015). In Belgorod, cooperatives do not generate any bargaining power themselves but instead are shielded from market competition by the state.

In turn, cooperatives were expected to recruit as many new member households as possible. From the regional government's perspective, this was one of the fundamental factors of the programme's success. It was also one of the indicators used by the regional administration to monitor the implementation of the programme at the district level. These sales channels were, de facto, controlled by the state. In the case of the vegetable cooperative we studied, state influence manifested itself through contracts between the cooperatives and municipal social organisations (such as schools and hospitals). Being one of the key sales channels of the vegetable cooperative, all of those contracts were signed at once rather than emerging gradually (Vegetable cooperative chairman, FGD, 20 October 2010). This suggests that those contracts did not result from free market competition but, instead, from the administrative decisions of the local authorities, which mediated between the cooperative and the social organisations. By being integrated in these sales channels, the cooperatives were largely shielded from the economic competition inside the region.

It is worth noting that market forces nevertheless played a considerable role here. Although the very small household producers had hardly any alternative sales channels, private farmers could only be motivated to conduct transactions with cooperatives by means of economic incentives. In the case of the large dairy cooperative we studied, the secure channels' only buyer was a milk factory, which, although private, was strongly influenced by the district authorities. For instance, when a conflict emerged between the milk factory and the dairy cooperative, the district head personally intervened and pressured the milk factory not to terminate its relationship with the cooperative (Dairy cooperative chairman, FGD, 20 October 2010). ${ }^{17}$ The private ownership of the milk factory did not preclude the authorities from using the same administrative negotiation practices used for creating a sales channel for the cooperative. 


\section{A conversion to what? Tensions and plans in top-down cooperatives}

The top-down nature of cooperatives is often claimed (or, more implicitly, expected) to discourage member involvement (Barton, 1989; Dunn, 1988), but this does not always have to be the case. In some cases, the authorities' interests and plans may coincide with those of the agricultural producers involved in the cooperatives. More importantly, as members continue to benefit from the cooperatives' services, and trust and involvement increase, the top-down cooperatives might become more appealing to potential members. While research on cooperatives generally approaches social capital as a prerequisite for the emergence of grassroots cooperatives, some authors argue that the existence of cooperatives might itself lead to an increase in social capital among members in the early phases, and contribute to community development (Zeuli \& Radel, 2005). As such, top-down established cooperatives can potentially be a solution in settings where social capital is too low to allow for the grassroots emergence of cooperatives (particularly, but not exclusively, in post-socialist countries). The question is whether top-down cooperatives can transform into more common cooperative forms within the post-socialist, Russian setting. Here we narrow down this issue and consider it in the Belgorod context. A transition towards the classic cooperative model would mean a gradual trend towards more member control and involvement. In the following sub-sections, we explore whether changes in this direction took place in the cooperatives we examined, and whether some stakeholders had plans to bring about such changes.

\section{Cooperative members: problems of identity}

To begin with, households, constituting the majority of the cooperative members, did not follow widely recognised cooperative principles. The case of the large dairy cooperative is quite illustrative here (FGD, 20 October 2010). In the beginning, it was difficult to convince households to join the cooperative. To incentivise them, the membership fee was very small, and the ordinary members had no financial responsibility for the cooperative's performance. In other words, there was a green light for every candidate. Without these measures, it would have been difficult to recruit any sizeable number of members. As officials from the Regional Department of Agriculture stated, 'Interest should grow from below. Cooperatives can be created from above, but the interest from below is necessary' (FGD with officials from the Belgorod Department of Agriculture, 23 October 2010). However, according to Ostrom's (1990) principles for common pool resource management, this practice should have its downsides. For instance, she argues that the boundaries of a local community or organisation should be clearly defined in order to effectively exclude unwanted participants, and to avoid a free rider problem. Moreover, a sanction system should be established against those who violate the community rules. ${ }^{18}$ The dairy cooperative failed to follow both of these principles, thus opening itself up to the following problems.

When discussing the difficulties the cooperative faced, the chairman noted - among other issues - the members' lack of attachment to the cooperative. Here, she referred to their opportunistic behaviour with regard to marketing their produce. ${ }^{19}$ For instance, they would sell their milk to itinerant traders from the neighbouring Voronezh region, who would then sell it to factories there. In this way, the milk was 'leaking' from the cooperative, thereby reducing its revenue. The cooperative management used this fact to explain the abrupt 
decrease in annual profits: in 2009, the cooperative had registered a profit of 2.6 million roubles, while the profit for 2010 was estimated to be approximately 1.3 million roubles.

The household members' reason for selling their milk to the itinerant traders was purely financial: in certain periods, traders offered higher prices than the cooperative. The cooperative's occasionally disadvantageous pricing practices came as a result of its contractual obligations towards its suppliers and purchasers - which decreased its flexibility - and the rigid price-making policy enforced by the state. ${ }^{20}$

That being said, while households were, at first, drawn away by the higher prices offered by the itinerant traders, they seemed to increasingly appreciate the benefits provided by the cooperative. According to the cooperative's chairman, the itinerant entrepreneurs frequently delayed payments to the households selling them their milk, because milk factories in turn delayed payments to them. Furthermore, the itinerant traders flexibly chose their suppliers, and would rapidly relocate from the district when lower-priced milk was offered elsewhere. Members increasingly preferred to work with the cooperative, because it provided a guaranteed outlet and stable prices and payment. Thus, the erosion of ties between the member households and the cooperative appeared to halt in time. Nevertheless, the households still enjoyed a double (or intermediate) position: although they generally sold milk to the cooperative, they could - and would - sometimes make profitable deals with outsiders. In other words, they did not (yet) act as true cooperative members. Thus, the cooperative's 'victory' was likely only a temporary equilibrium.

Nevertheless, it is important to note that the crucial factor in the households' decisions to become cooperative members was the advantages the cooperative held over other marketing outlets - such as stable pricing and long-term contracts. Of course, part of these advantages resulted from the cooperative's state-led (and state-protected) character, and the outlet's cooperative nature itself. The stability it provided would be difficult to achieve by purely commercial purchasers. Moreover, except for the already mentioned small-scale itinerant traders, commercial purchasers are generally not interested in small-scale producers, opting for larger-scale producers with lower transaction costs.

\section{The cooperative's management: prevailing business logic}

Although the large dairy cooperative's members behaved opportunistically and lost sight of the cooperative's interests, the management paid little attention to increasing the households' involvement in the cooperative's decision-making, or to actively encourage the households to invest in the cooperative. The management perceived such efforts as fruitless and/ or very costly (instead, they focused on direct economic incentives through delivered services only). In fact, business logic rather than cooperative logic seemed to inform the management's actions in all three cooperatives that were part of our field study - something which would, over time, result in a narrower pool of household members. First, in the case of all three cooperatives, the management increasingly aimed to focus on a limited group of medium-sized and/or high quality producers, rather than targeting as many households in the district as possible. Second, the management of the large dairy cooperative and the vegetable cooperative consistently referred to'profits' during our conversations. In the case of the small dairy cooperative, the management indicated that it sought an expansion into higher-end market outlets, which would exclude the household members as suppliers. While classic cooperatives might produce a profit, the sum is redistributed to the members in the 
form of patronage payments. As previously mentioned, this contradiction with cooperative principles stems from the perception - both by the members and the management - of the cooperative as a simple outlet, or mediator between farmers and processing companies. The studied cooperatives are, de facto, in the hands of their management - namely, the actors who invested financial resources (and should therefore, according to business logic, receive all the profit). ${ }^{21}$ Thus, it is not surprising that the management of the studied cooperatives were using market terminology and pursuing market logic goals (such as targeting higher-end markets), instead of targeting the needs of the member households. When asked whether they distribute the cooperative's profit among its members, the manager of the small dairy cooperative, for instance, answered, 'In general, initially, we imagined it like that. But I can say that we have, currently, unfortunately, already stopped doing so' (FGD November 2013).

We can further trace the signs of market logic in the long-term goals of the large dairy cooperative's management. The management planned to shift its focus over time towards relatively large suppliers (in terms of the cattle number per household). The cooperative was interested in households with diversified, small-scale, semi-subsistent production that would enlarge and eventually specialise in keeping 10-20 cows. As the ideal example, the cooperative's chairman described a household member that was keeping 46 cows and using a small refrigerator - an example which clearly resembles an average private family farm more than a household plot. The chairman of the small dairy cooperative even stated that 'there is a strong desire to change the ownership form' [namely into a limited liability company] (FGD November 2013).

\section{The state vs. cooperative management: confronting logics}

The fact that the cooperatives' management had not implemented their planned strategies by the end of the data collection period was largely due to the influence of the district authorities. Without doubt, it would be much easier to deal with the large household producers the management envisioned, as they would decrease transport and testing costs. However, in the eyes of the district administration, this logic would oppose the cooperatives' goals, which - as seen by the administration - should be primarily social rather than economic. As mentioned earlier, the goal of the district and regional administrations was to increase the households' livestock numbers, in order to increase rural incomes and combat poverty, inequality and rural depopulation (Belgorod Government, 2007). Focusing on a few larger household producers would go against these social goals.

There are no indications (yet) of a transformation to a classic, member-based cooperative. From the side of the members, there is significant opportunistic behaviour, and practically no involvement. From the side of the management there are no plans to further the involvement of members. On the contrary, the management follows business logic that would lead to the exclusion of a large proportion of the members, were it to be enforced as planned. As mentioned above, one cooperative's management even explicitly stated that it would like to convert into a conventional company. It is the authorities that prevent such a development. Thus goal congruence between the various stakeholders, which tends to decline over the course of a cooperative's life cycle (Hind, 1999), was, in the case of the Belgorod region, largely prevented by state pressure on the management to continue to nurture a wide constituency of rural households. 


\section{Conclusions}

The first question the article dealt with was: how much influence does the state exert on these top-down established cooperatives? Based on our field study in the Belgorod region, we have shown that, beyond the establishment process, the state also had a strong influence on the cooperatives' daily operations. For instance, through administrative bargaining with economic actors in the agrofood sector, the state had created secure sales channels for the cooperatives. This state influence had both benefits and drawbacks. On the positive side, it ensured guaranteed sales for the cooperatives, and, subsequently for the households they targeted.22 Furthermore, the state's influence on price setting within the sales channel led to stable farm gate prices for the rural households. On the negative side, the cooperatives and households could not profit from temporary price increases, as the state exerted a certain pressure to keep regional food prices down. In addition, it made cooperatives dependent on governmental protection, which calls their competitiveness into question. There is no indication that authorities plan a phasing out of state protection.

Although we presented various tensions and shortcomings associated with the top-down cooperatives we studied, it should be noted that the small-scale producers targeted by the cooperatives face a rather hostile economic environment (see e.g. Pallot \& Nefedova, 2007). Our findings suggest that cooperatives in the Belgorod region positively affected the household producers' subsistence. The cooperatives provide a stable sales channel, which in itself makes a significant difference to the rural dwellers.

Our findings regarding top-down established cooperatives are clearly less negative than those of Golovina and Nilsson $(2009,2011)$. The difference seems to stem from the goals of the regional authorities. In Kurgan, they only set out to establish the number of cooperatives required by the federal authorities, whereas in Belgorod, they formulated a regional vision on rural development, which viewed cooperatives as an important building block.

The second question we raised at the beginning of the article was whether top-down cooperatives could form the basis for a (gradual) conversion towards less state-led cooperatives, whose members are more involved. As our fieldwork took place in only one region it being quite divergent form the majority of Russian regions - our answer to this question is only tentative, and looks to Russia's pre-Soviet history for potentially added relevance. As previously mentioned, Russia was at the forefront of the European cooperative movement during its late Imperial era. Historians have argued that, during the movement's first phase, cooperatives were enforced by the government (Figurovskaya \& Pirumova, 1991). Initially, the state's financial support to cooperatives far exceeded their members'financial contributions; over time, the cooperatives evolved to become more member-based and member-controlled.

We could not find any indication that a conversion towards a more member-based/controlled cooperative model was taking place in Belgorod. Neither the state, nor the cooperative management, nor yet the cooperatives' members expressed an interest in achieving this. Moreover, even if the authorities and management made this the cooperatives' goal, the conversion would be far from certain. In the short and medium term, conversion into more profit-oriented, business-like cooperatives would be more likely, especially if the regional authorities were to end their support, and/or their requirements regarding the cooperatives' social role. The shift towards prevailing business logic seems to be true for Russia in general. ILO $(2009$, p. 15) reports that the agricultural marketing cooperatives in 
Russia showed a decline in their numbers 'due to their stepping out of limits of their sphere of business activity, with the purpose of raising profitability of trading operations'. In the long term, for the widespread emergence of agricultural cooperatives to occur in a setting of scarce social capital and weak market institutions for small-scale farms (as is the case in Russia), strong government support seems to some scholars to be the only resort (cf. Efendiev \& Sorokin, 2013).

The conversion towards a more member-controlled cooperative type was also far from smooth in imperial Russia. Although the Tsarist state made significant efforts to promote cooperatives and cooperative values among the rural population (a policy currently lacking at the federal level), the early results were mixed (Figurovskaya \& Pirumova, 1991). In some regions, the cooperative movement did not take off at all; in others, fictitious cooperatives were established in order to launder state money (Figurovskaya \& Pirumova, 1991). Nevertheless, as time passed and more resources were spent, a more grassroots cooperative movement emerged, and the number of cooperatives experienced explosive growth. This turned Russia into one of the world leaders in the cooperative movement, with cooperatives constituting, in the words of Bilimovich ([1955] 2005, p. 73), 'one of the cornerstones of the overall Russian economic system'.

Currently, Russian cooperatives are far from becoming a cornerstone of the agricultural sector. Significant 'building work' must be done, and the phase to come (which, among other goals, would target the creation of member attachment) is likely to be much more difficult than the previous one. The cooperative examples we described from the Belgorod region are a first step in this development, as the cooperatives - while not member-controlled nevertheless are member-oriented, and benefit a wide range of rural dwellers. ${ }^{23}$ In this context, it is good to remember that classic cooperatives in various Western European countries were strongly supported by the government in their early stages (although not to the point where they would be shielded from market competition). While in Denmark and the Netherlands - the countries mostly referred to as the classical examples of early European cooperatives - the development of cooperatives was strongly bottom-up, with very limited state involvement (Svendsen \& Svendsen, 2001), in other countries - such as Belgium, France, and Italy - the state played a much more important role (Gutiérrez et al., 2005, Millns, n.d.). ${ }^{24}$ Thus, in order to better understand agricultural cooperatives in Russia, aside from more empirical research (both qualitative, quantitative and mix methods), it is important to expand our comparisons beyond the classic historical examples of Denmark and the Netherlands, which are the generally chosen point of reference (whether explicitly or implicitly). Specifically, it would be helpful to make use of historical examples where the state was relatively more involved in the development of agricultural cooperatives - whether from European countries in general, or (post-)socialist and/or emerging economies, such as China.

\section{Notes}

1. There are quite a number of journals specifically focused on cooperatives. Some of them are long established such as RECMA (founded in 1921) and Annals of Public and Cooperative Economics (founded in 1908), while others were founded recently such as the Journal of Co-operative Organization and Management (published from 2013). Although they are not exclusively focused on agricultural cooperation, rural issues are widely represented in studies on cooperatives. Journal of Cooperatives has agrarian roots (it was formerly called Journal of Agricultural Cooperation). Finally, we mention the Journal of Rural Cooperation (published by 
The Hebrew University of Jerusalem) which is currently inactive. Obviously, publications on cooperative issues can also be found in other, non-specialised, journals. However, cooperatives currently seem to have become a marginal topic, with few scholars working on it (for instance in economics, see Kalmi, 2007) and many of the journals on cooperatives are indexed neither by WoS nor Scopus.

2. This reflects the wider global trend that attention to cooperatives has declined since the $1980 \mathrm{~s}$ (see e.g. Kalmi, 2007; Mazzarol, Reboud, Limnios, \& Clark, 2014 ).

3. With regard to rural movements engaged in political issues, such as the struggle for protection of land rights of the rural population against raiders, the increased restrictions on civil society and attempts to embed such organisations in the state in order to control them are an important cause of the weakness of rural organisations (Mamonova \& Visser, 2014). In the case of agricultural cooperatives, which only have a socio-economic orientation, this does not seem to play a role.

4. International comparative studies provide some indicators of the low level of social capital in Russia at large. For example, the World Bank (2006) survey indicates a low level of intangible capital in Russia (which includes human capital, social capital, governance etc.). We have to note though, that such general indicators should be treated with caution. Some case studies of rural areas confirm those results (Small, 2002) while others confront them providing a more nuanced vision (Patsiorkovsky, 2003). For instance, Small in her case study focuses on collective actions arguing that there are'no community organisations, formal co-operation or volunteer activity' and investigates the 'influence of a command society on social capital formation'. Patsiorkovsky points out that social capital could be found not only in organisations but also in kinship network structures (relatives, neighbours, friends). So, those are different dimensions of social capital. Here we refer to social capital as the basis for collective action in Putnam's (2000) sense. While rural households' social capital in the form of informal networks (mainly presented in kinship ties) have even increased as a response to shock therapy reforms in various cases (see O'Brien, Patsiorkovski, \& Dershem, 2000; O'Brien, Wegren, \& Patsiorkovsky, 2005), participation in community-wide activities has clearly declined (O'Brien et al., 2000, 2005; Visser, 2008). Thus social capital on the level of rural communities remains low, hindering cooperation beyond kinship circles.

5. This is not only relevant in the Russian context. In the majority of post-socialist countries, cooperative-related problems are especially acute due to the low levels of trust and social capital in rural society at large (Millns, 2013; O'Brien et al., 2005; Tisenkopfs, Kovách, Lošták, \& Šumane, 2010), the legacies of the (semi)totalitarian socialist systems, and the economic chaos, rent seeking behaviour, and general opportunism generated during the shock therapy reforms in the early 1990 s.

6. The grassroots nature of cooperatives is emphasised in the cooperative literature and ideology from the very beginning (i.e. the Rochdale, Raiffeisen and then ICA cooperative principles; see also Dunn, 1988). For instance, Zeuli and Cropp's (2004) textbook ignores the issue of top-down cooperatives. Moreover, Mazzarol et al. (2014) refer to Kalmi (2007), who argues that economics has lost interest in cooperative studies partly because it began to focus more on top-down rather than bottom-up solutions to economic problems. Kalmi thus implies the primacy of the bottom-up nature of cooperatives in the (economic) scholarly literature.

7. Recently, Petruchenya and Hendrikse (2014) suggested a more balanced approach to the emergence of cooperatives, where their top-down creation (associated mainly with nonWestern countries) is viewed as a possible path of cooperative establishment. However, they focus on formal economic game modelling, while we focus on empirical evidence.

8. Belgorod has always been among the leading agrarian regions in Russia due to fertile soils and a favourable climate. However, its recent success in agriculture relies on intensification of production, rather than on extensive development, as in some other Russian regions (e.g. those with vast surfaces of arable land in Western Siberia).

9. In some regions and sub-sectors (e.g. grain), the emergence of farmers has been rather substantial (Pallot \& Nefedova, 2007). Moreover, some authors have recently evaluated the farmer movement in a more positive light (Wegren, 2011). 
10. Trends in the literature on cooperatives in Russia are reflected in the collective monograph 'The state and prospects of consumer cooperation in Russia' that will be published by Tsentrosoyuz (Busygin, in press).

11. One of the main contributors to the law 'On agricultural cooperation' V. Vershinin (2015) explicitly points out that one of the general purposes of the double nature (reflected in the law) of Russian agricultural cooperatives (consumer versus production cooperatives) was to give collective farms the option to preserve their status in the decollectivisation process during the agrarian reforms of the 1990s, by registering as production cooperatives. Thus, production cooperatives could be called post-Soviet kolkhozes.

12. For example, the resolution of the second section ('The development of agricultural consumer and service cooperation') of the first Russian congress of rural cooperatives notes that 'this type of cooperation is in its infancy' (Proceedings, 2013, p. 27). ILO (2009, p. 15) speaks with regard to agricultural service cooperatives about the 'inertness of its development process', although it notes that there are regional differences. According to Yanbykh et al. (2012), the leading regions in Russia are Volgograd, Tyumen, Mordovia and Yakutia. In Lipetsk region, the regional programme for cooperative development resembles Belgorod's top-down experience (Lipetsk Government, 2012). However, the lack of research on Lipetsk (as on most other regions) precludes making comparisons that are more detailed.

13. Supply cooperatives here serve as substitutes to consumer societies in the Tsentrosoyuz system, which was established as part of the Soviet cooperative system to provide rural areas with consumer goods and procure agricultural products from rural households. The Tsentrosoyuz cooperative organisation survived in reduced form after the collapse of socialist agriculture (http://www.rus.coop/en/about-us/figures/).

14. The only two options that were available to household milk producers before the establishment of the cooperative were individual traders and the district's central market (or 'farmers' market'). Before the emergence of the cooperatives, households tended to get rid of their cows due to many reasons including the lack of appropriate market channels to sell their milk, in line with the general tendency in the Russian countryside of households reducing their livestock including cows, pigs and chickens (Rosstat, 2015). The establishment of cooperatives stimulated households in Belgorod to keep their cows.

15. This is the general perception among policy makers, agro-business representatives and most of the rural population, although - for various products - household plots and family farms have yields that are quite close to, or even equal to, those of large farm enterprises (see e.g. Visser, Mamonova, Spoor, \& Nikulin, 2015 for different views and data on production).

16. 'Tens of thousands of self-employed individuals live in the Belgorod region by making use of their household plots. As a rule, they have a low income because of the primitive agriculture they employ, and the lack of sales channels.' According to the programme's authors, its goal is to fight self-reproducing poverty in rural areas by developing rural entrepreneurship (Belgorod Government, 2007).

17. While district and regional authorities are able to influence district and regional level enterprises, that is much harder with regard to very large companies operating countrywide, such as supermarket chains (FGD small dairy cooperative, 6 November 2013).

18. The other six principles are the following: (1) fitting the rules that govern the use of common resources to the local conditions; (2) ensuring that resource appropriators participate in decision-making; (3) effectively monitoring members' behaviour; (4) establishing cheap and easy mechanisms of conflict resolution; (5) ensuring the recognition of outside authorities; and (6) developing a multilayered organisation (if common pool resources are large).

19. It shows that the management of those top-down cooperatives often clearly understands the low involvement of their members, but it treats this situation as a given, i.e. it does not attempt to increase members' loyalty but tries to find solutions under the condition of a low level of loyalty.

20. The cooperative was constrained from increasing its sales prices, due to pressures from the regional authorities, who aimed to keep the district's end-consumer prices low.

21. Although, as discussed earlier, with substantial state influence (see also next section). 
22. This arrangement is not unique. For example, in Brazil the state obligated schools to purchase food only from small-scale producers (IPC-IG, 2013; Otsuki, 2012).

23. As mentioned earlier, in the case of the small dairy cooperative, the member orientation was present initially but declined later.

24. Millns (n.d., p. 5), for example, states that 'probably only Holland and Denmark could argue strongly that competitive market-based agricultural cooperatives developed with relatively little State support'. In both countries, 'the culture of "cooperation"' is 'well integrated through many aspects of society at an early age', which is not always the case in most other Western countries. For more on the development of the two divergent cooperative models in Europe, see Gutiérrez et al. (2005).

\section{Acknowledgements}

The authors thank all the interviewees, FGD participants and the people in Belgorod who helped establishing contacts for the field research. We are grateful to the Director of the Center for Agrarian Studies at RANEPA, A. Nikulin, and Professor T. Kuznetsova of the Institute of Economy (RAS) for their valuable comments on an earlier draft of this article. Support from the Basic Research Program of the National Research University Higher School of Economics is gratefully acknowledged by Kurakin. Support from the European Research Council (ERC) is gratefully acknowledged by Visser.

\section{Disclosure statement}

No potential conflict of interest was reported by the authors.

\section{Funding}

Support from the Basic Research Program of the National Research University Higher School of Economics is gratefully acknowledged by Kurakin. The fieldwork conducted by Visser was financed by the European Research Council (ERC) [Grant No. 313871].

\section{References}

Alekseevsky municipal government. (2011). Informatsiya ob itogakh sotsial'no-ekonomicheskogo razvitiya munitsipal'nogo raiona 'Alekseevskii raion i gorod Alekseevka'za 2010 god [Information about the results of socio-economic development of the municipal region 'Alekseevsky district and town Alekseevka' in 2010]. Retrieved from March 3, 2011

Amelina, M. (2000). Why Russian peasants remain in collective farms: A household perspective on agricultural restructuring. Post-Soviet Geography and Economics, 41, 483-511.

Barsukova, S. (2007). Prioritetnyi natsional'nyi proekt 'Razvitie APK': ideya i realizatsiya [The priority national project 'Development of AIC': Idea and implementation]. Voprosy statistiki, 11, 19-31.

Barton, D. (1989). Principles. In D. Cobia (Ed.), Cooperatives in Agriculture (pp. 21-34). Englewood Cliffs, NJ: Prentice Hall.

Belgorod Government. (2007). Oblastnaya tselevaya programma 'Semeinye fermy Belogor'ya [Regional target programme 'Belgorod family farms'], Ratified by the Belgorod government on 18 June 2007 (Act No.134).

Bijman, J., Lliopoulos, C., Poppe, K. J., Gijselinckx, C., Hagedorn, K., Hanisch, M., ... van der Sangen, G. (2012). Support for farmers' cooperatives. European Commission: Final report.

Bijman, Jos, \& Hendrikse, George (2003). Co-operatives in chains: Institutional restructuring in the Dutch fruit and vegetable industry. Journal on Chain and Network Science, 3, 95-107.

Bilimovich, A. ((1955)2005). Kooperatsiya v Rossii do, vo vremya i posle bol'shevikov [Cooperation in Russia before, during and after Bolsheviks]. Moscow: Nauka. 
Chayanov, A. ((1927)1991). The theory of peasant co-operatives. Columbus, GA: Ohio State University Press.

Busygin, A. (ed.) (in press). Sostoyanie i perspektivy razvitiya potrebitelskoy kooperacii v Rossii [The state and prospects of consumer cooperation in Russia]. Moscow.

Deng, H., Huang, J., Xu, Z., \& Rozelle, S. (2010). Policy support and emerging farmer professional cooperatives in rural China. China Economic Review, 21, 495-507.

Dunn, J. R. (1988). Basic cooperative principles and their relationship to selected practices. Journal of Agricultural Cooperation, 3, 83-93.

Efendiev, A., \& Sorokin, P. (2013). Rural social organization and farmer cooperatives development in Russia and other emerging economies: Comparative analysis. Developing Country Studies, 3, 106-115.

Epshtein, D., Hahlbrock, K., \&Wandel, J. (2013). Why are agroholdings so pervasive in Russia's Belgorod oblast'? Evidence from case studies and farm-level data. Post-Communist Economies, 25, 59-81.

Fedorov, N. (2013). Kooperatsiya kak 'tret'ya sila' [Cooperation as a 'third force']. Materialy pervogo vserossiiskogo s"ezda sel'skikh kooperativov 21-22 marta 2013, Sankt-Peterburg [Proceedings of the First Russian Congress of Rural Cooperatives 21-22 March 2013, St.Petersburg], Moscow, 43-48.

Figurovskaya, N., \& Pirumova, N. (Eds.). (1991). Kooperatsiya: stranitsy istorii [Cooperation: Pages of history] (Vol. 1). Moscow: Nauka.

Franks, J., \& Davydova, I. (2005). Reforming the farming sector in Russia: New options for old problems. Outlook on Agriculture, 34, 97-103.

Gardner, B., \& Lerman, Z. (2006). Agricultural cooperative enterprise in the transition from socialist collective farming. Journal of Rural Cooperation, 34(1), 1-18.

Golovina, S. (2012). Agricultural cooperation. From past to present. In C. Jakobsson (Ed.), Ecosystem health and sustainable agriculture. Vol.1. Sustainable agriculture (pp. 440-443). Uppsala: Baltic University Press.

Golovina, S., Hess, S., Nilsson, J., \& Wolz, A. (2014). Social capital in Russian agricultural production cooperatives. Post-Communist Economies, 26, 522-536.

Golovina, S., \& Nilsson, J. (2009). Russian agricultural producers' views of top-down organized cooperatives. Journal of Rural Cooperation, 37, 225-241.

Golovina, S., \& Nilsson, J. (2011). The Russian top-down organised co-operatives - reasons behind the failure. Post-Communist Economies, 23, 55-67.

Golovina, S., Nilsson, J., \& Wolz, A. (2012). The development of agricultural production cooperatives in Russia. Journal of Rural Cooperation, 40, 43-58.

Golovina, S., Nilsson, J., \& Wolz, A. (2013). Members' choice of production co-operatives in Russian agriculture. Post-Communist Economies, 25, 465-491.

Gorton, M., Angell, R., Dries, L., Urutyan, V., Jackson, E., \& White, J. (2015). Power, buyer trustworthiness and supplier performance: Evidence from the Armenian dairy sector. Industrial Marketing Management, 50, 69-77.

Goskomstat. (2000). Sel'skoe khozyaistvo v Rossii [Russian agriculture]. Moscow: Goskomstat.

Gutiérrez, C., Atela, T., \& Duenas, D. (2005). A comparative synthesis of 20th century agricultural cooperative movements in Europe. Journal of Rural Cooperation, 33, 47-65.

Hind, A. M. (1999). Co-operative life cycles and goals. Journal of Agricultural Economics, 50, 536-548.

Humphrey, C. (1999). Traders, 'disorder', and citizenship regimes in provincial Russia. In M. Burawoy \& K. Verdery (Eds.), Uncertain transition: Ethnographies of change in the postsocialist world (pp. 19-52). Lanham, MD: Rowman \& Littlefield.

ILO (2001). Promotion of cooperatives. International labour conference, 89th session, report V (1), 5-21 June 2001, Geneva. Geneva: International Labour Office.

ILO (2009). Cooperative sector in Russia and the implementation of the ILO recommendation no. 193 in the development of different Russian cooperative trends. Analytical report. Moscow: International Labour Office.

IPC - IG (2013). Structured demand and smallholder farmers in Brazil: The case of PAA and PNAE. Brasilia, Brazil: International Policy Centre for Inclusive Growth (IPC - IG). Retrieved July 28, 2015, from http:// www.ipc-undp.org/pub/IPCTechnicalPaper7.pdf

Kalmi, P. (2007). The disappearance of cooperatives from economics textbooks. Cambridge Journal of Economics, 31, 625-647. 
Kotsonis, Y. (1999). Making peasants backward: Agricultural cooperatives and the agrarian question in Russia, 1861-1914. Basingstoke: Macmillan.

Kurakin, A. (2012). Belgorodskie sel'skokhozyaistvennye kooperativy: mezhdu administratsiei, rynkom i soobshchestvamy [Belgorod agricultural cooperatives: Between administration, market and communities]. In A. Nikulin, M. Pugacheva, \& T. Shanin (Eds), Krestyanovedenie. Teoriya. Istoriya. Sovremennost'. Uchenye zapiski [Peasant studies. Theory. History. Modernity] (Vol. 7, pp. 312-344). Moscow: Delo.

Lerman, Z. (2013). Cooperative development in Central Asia. FAO policy studies on rural transition 2013-4. Rome: FAO.

Liang, Q., \& Hendrikse, G. (2013). Core and common members in the genesis of farmer cooperatives in China. Managerial and Decision Economics, 34, 244-257.

Lin, J., \& Huang, S. (2007). Member heterogeneity and ownership rights in farmer cooperatives. Agricultural Economy Issue, 10, 12-17.

Lipetsk government (2012). Oblastnaya tselevaya programma "Razvitie kooperatsii v Lipetskoy oblastina 2013 - 2020 gody" [Regional target programme 'development of cooperation in Lipetsk region for 2013-2020'], Ratified by the Lipetsk government on 15 October 2012 (Act No.416).

Mamonova, N., \& Visser, O. (2014). State marionettes, phantom organisations or genuine movements? The paradoxical emergence of rural social movements in post-socialist Russia. Journal of Peasant Studies, 41, 491-516.

Mazzarol, T., et al. (Eds.). (2014). Research handbook on sustainable co-operative enterprise: Case studies of organisational resilience in the co-operative business model. Cheltenham: Edward Elgar.

Mendoza, E., \& Castillo, E. (2006). The path to the success of cooperatives. The University of Philippines Press.

Millns, J. (2013). Agriculture and rural cooperation: Examples from Armenia, Georgia and Moldova. FAO regional office for Europe and Central Asia. Policy studies on rural transition, No. 2013-2.

Millns, J., (n.d.). Policies and programmes to support farmer and rural organisations in Central and Eastern Europe. Meden Consultants. Retrieved July 28, 2015, from www.fao.org/fsnforum/sites/.../John_ Mills_Paper_cooperative_0.doc

Murray, C. (2006). Social capital and cooperation in Central and Eastern Europe: Toward an analytical framework. Poster paper prepared for presentation at the International association of agricultural economists conference, Gold Coast, Australia, August 12-18.

Nikulin, A. (2003). Kuban kolkhoz between a holding and a hacienda. Contradictions of post-soviet rural development. Focaal, 41, 161-176.

Nikulin, A. (2009, January 12). Missiya krest'yanstva i obyazannosti gosudarstva [Peasants' mission and state obligations]. Krest'yanskie vedomosti.

Nilsson, J., Golovina, S., \& Volodina, N. (2008). Vliyanie doveriya na razvitie agrarnykh kooperativov [The role of trust in agricultural cooperatives development]. Agrarnyi vestnik urala, 50, 11-13.

Nilsson, J., Volodina, N., \& Golovina, S. (2010). Agrarnaya kooperatsiya v Rossii: problemy vybora organizatsionnoi modeli [Agricultural cooperation in Russia: The problem of organisation model choice]. Ekonomika i upravlenie, 7, 12-17.

O'Brien, D., Patsiorkovski, V., \& Dershem, L. (2000). Household capital and the Agrarian problem in Russia. Burlington: Ashgate.

O'Brien, D., Wegren, S., \& Patsiorkovsky, V. (2005). Marketization and community in post-soviet Russian villages. Rural Sociology, 70, 188-207.

Ostrom, E. (1990). Governing the commons: The evolution of institutions for collective action. Cambridge, N.Y.: Cambridge University Press.

Otsuki, K. (2012). The local food revolution in Brazil's schools. Solutions, 3 (6). Retrieved July 28, 2015, from http://www.thesolutionsjournal.com/node/1178

Pallot, J. (Ed.). (1998). Transforming peasants: Society, state and the peasantry, 1861-1930. Basingstoke: Macmillan.

Pallot, J., \& Nefedova, T. (2007). Russia's unknown agriculture. Household production in post-socialist rural Russia. Oxford: Oxford University Press.

Patsiorkovsky, V. (2003). Sel'skaja Rossija: 1991-2001 [Rural Russia: 1991-2001]. Moscow: Finansi i Statistika? https://www.ozon.ru/context/detail/id/1423845/ 
Petruchenya, A., \& Hendrikse, G. (2014). Emergence of cooperatives and farmer heterogeneity. Paper prepared for presentation at the EAAE 2014 Congress 'Agri-Food and Rural Innovations for Healthier Societies', Ljubljana, Slovenia, 26-29August 2014.

Proceedings. (2013). Materialy pervogo vserossiiskogo s"ezda sel'skikh kooperativov 21-22 marta 2013, Sankt-Peterburg [Proceedings of the First Russian Congress of Rural Cooperatives 21-22 March 2013, St.Petersburg], Moscow.

Putnam, R. (2000). Bowling alone: The collapse and revival of American community. New York, NY: Simon and Schuster.

Rosstat. (2002, 2004, 2013a). Sel'skoe khozyaistvo, okhota i okhotnich'e khozyaistvo, lesovodstvo v Rossii [Agriculture, hunting and forestry in Russia]. Moscow: Rosstat.

Rosstat. (2006, 2009). Osnovnye pokazateli sel'skogo khozyaistva v Rossii [Basic indicators of agriculture in Russia]. Moscow: Rosstat.

Rosstat. (2013b). Regiony Rossii. Sotsial'no-ekonomicheskie pokazateli [Russian regions: Socio-economic indicators]. Moscow: Rosstat.

Rosstat (2014). Russia in figures: Statistical handbook. Moscow: Rosstat.

Rosstat (2015). Sel'skoe khozyaistvo, okhota i okhotnich'e khozyaistvo, lesovodstvo v Rossii [Agriculture, hunting and forestry in Russia]. Moscow: Rosstat.

Russian ministry of agriculture (2013). Natsionalnyi doklad 'O khode i resul'tatakh realisatsii $v$ 2012 godu gosudarstvennoi programmy razvitiya sel'skogo khosyaistva i regulirovaniya rynkov sel'skokhosyaistvennoi produktsii, syr'ya i prodovol'stviya na 2008-2012 gody' [National report 'About the results in 2012 of the state program for agricultural development and regulation of agricultural products, commodity, and food markets for 2008-2012']. Moscow: FGNU “Rosinformagrotech". http:// www.mcx.ru/navigation/docfeeder/show/297.htm

Rankin, M. K., \& Russell, I.W. (2005). Building sustainable farmer cooperatives in the Mekong delta, Vietnam: Is social capital the key? Paper presented at the Conference on engaging communities, Brisbane, 17 August.

Shanin, T. (Ed.). (1971). Peasants and peasant societies. Selected readings. Middlesex and Baltimore: Penguin Books.

Small, L.-A. (2002). Social capital for development: What does it mean if there isn't any? A case study of agricultural producers in Dmitrov rayon. Russia. Canadian Journal of Development Studies, 23, 7-25.

Sultan, T., Larsén, K., \& Huang, Z. (2011). Learning by doing-farmers'specialized cooperatives development in China. Paper presented at the 5-th International European forum on system dynamics and innovation in food supply networks, Innsbruck-Igls, Austria, 14-18 February 2011.

Svendsen, G. L., \& Svendsen, G. T. (2001). Alleviating Poverty: Entrepreneurship and social capital in rural Denmark 1800-1914. Revue Belge de geographie, 3, 231-246.

Tisenkopfs, T., Kovách, I., Lošták, M., \& Šūmane, S. (2010). Rebuilding and failing collectivity: Specific challenges for collective farmers marketing initiatives in post-socialist countries. International Journal of Sociology of Agriculture and Food, 18, 70-88.

Uzun, V. (2005). Large and small business in Russian agriculture: Adaptation to market. Comparative Economic Studies, 47, 85-100.

Vershinin, V. (2015). Sel'skohozjajstvennaja kooperacija. Rozhdenie zakona [Agricultural cooperation. The birth of the law]. Moscow.

Visser, O. (2003). Family farms, community and the decline of the former kolkhozi in Russia. In H. Grandits \& P. Heady (Eds.) Inheritance and change in rural Europe. Transformation in modern and contemporary systems of family, property and community (pp. 313-28). Munster: LIT Verlag.

Visser, O. (2008). Crucial connections. The persistence of large farm enterprises in Russia (PhD Thesis in Anthropology and Development Studies). Radboud University, Nijmegen.

Visser, O. (2009). Household plots and their symbiosis with large farm enterprises in Russia. In M. Spoor (Ed.), The political economy of rural livelihoods in transition countries. Land peasants and rural poverty in transition (pp. 76-98). London: Routledge.

Visser, O. (2010). Insecure Land Rights, Obstacles to Family Farming and the Weakness of Protest in Rural Russia. Laboratorium, 2, 275-295.

Visser, O., Mamonova, N., Spoor, M., \& Nikulin, A. (2015). 'Quite food sovereignty' as food sovereignty without movements? Insights from post-socialist Russia. Globalizations, 12, 513-528. 
Wegren, S. (1998). Agriculture and the state in Soviet and post-Soviet Russia. Pittsburgh, PA: University of Pittsburgh Press.

Wegren, S. (2011). Private farming in Russia: An emerging success? Post-Soviet Affairs, 27, 211-240.

White, J., Gorton, M. (2006). A comparative study of agrifood chains in Moldova, Armenia, Georgia, Russia, Ukraine. In J. Swinnen, (Ed.), Case studies on the dynamics of vertical coordination in the agrifood chains of transition countries in Eastern Europe and Central Asia. ECSSD Working Paper No.42 (pp. 5-43). Washington DC: The World Bank.

World Bank. (2006). Where is the wealth of nations? Measuring capital for the 21-st century. Washington, D.C.: The World Bank.

Yanbykh, R., Starchenko, V., Mindrin, A., Tkach, A., \& Krylov, V. (2012). Monitoring deyatel'nosti sel'skokhozyaistvennykh potrebitel'skikh kooperativov [Monitoring of the agricultural consumer cooperatives' performance]. In Sostoyanie i perspektivy razvitiya kooperatsii v agrarnom sektore ekonomiki [Conditions and perspectives of the cooperation development in the agrarian sector]. Moscow. Retrieved July 28, 2015, from www.viapi.ru/publication/e-biblio/detail.php?!BLOCK_ ID $=45 \& S E C T I O N \_I D=1069 \& E L E M E N T \_I D=30941$

Zeuli, K., Cropp, R. (2004). Cooperatives: Principles and practices in the 21st century. University of Wisconsin-Extension, Madison, Wisconsin, USA.

Zeuli, K., \& Radel, J. (2005). Cooperatives as a community development strategy: Linking theory and practice. The Journal of Regional Analysis and Policy, 35, 43-54. 